\title{
The Contents Methods of Teaching and the Place of Accounting in the Tourism Study Curriculum: (Case Study)
}

\author{
Desa Kosarkoska \\ University "St. Kliment Ohridski" - Bitola, Faculty of Tourism and Hospitality - Ohrid
}

\begin{abstract}
Accounting as a study subject is part of any contemporary curriculum for studying Tourism and Hospitality management. Now days we can see very similar studying programs of accounting in different curriculums. The reason for this is the fact that accounting as an information system designed to provide the financial information required by various groups of people is imperative present in each economy entity. The aim of this paper is analyze the study program of accounting as a subject of curriculum on Faculty of Tourism and Hospitality - Ohrid, St. Kliment Ohridski University - Bitola, R. of Macedonia, in order to determine the methods of teaching and the strengths and weaknesses of this program as well. Making a comparative sight of this study program with other studying Tourism and Hospitality contemporary programs is the objective as well.
\end{abstract}

Keywords: Accounting, Curriculum, Tourism and Hospitality, Students, Method of teaching.

\section{Introduction}

The rapid expansion of tourism education and recent years reflects the growing recognition of tourism (and the travel industry that serves it) as one of the world's most significant economic, social, and environmental forces. The development of the various levels of education and training in the subject area, ranging from highly vocational courses through to higher research degrees, reflects the widely help belief that one of the major challenges the industry faces is to recruit, develop and retain employees and managers with appropriate educational background.

\section{Tourism as an Area of Study}

\subsection{Background}

Nowadays there's an opinion that tourism as an area of study is difficult to classify. This is reflected in the development of tourism education from a variety of different subject perspectives. The design of appropriate curricula for tourism has been influenced by three factors that sometimes have exerted divergent influences upon degree courses.

First, an academic debate has emerged focusing on where tourism studies should fit within the overall framework of knowledge and education. This debate has focused on the inherent difficulties in classification and definition of the tourism phenomena due to its complex nature.

Second, a debate has taken place as to the role tourism studies should play in terms of serving the industry.

Third, the tourism curriculum has been influenced by the growing body of specialist literature that has developed, particularly since the launch of major journals in the 1970s.

\subsection{Globalization and Tourism Education}

It is widely asserted that we live in an era in which the greater part of social living is determinate by global process, in which national cultures, national economises, and national borders are dissolving. Tourism is a major aspect of the global economy, with all countries, whether developed or developing, having increasing opportunities to participate, as both hosts and guests, in this socio-economic phenomenon.

Globalization is leading to increased emphasis on internationalization of the curriculum in general. For the tourism curriculum educators should reflect on the question whether the present framework they have developed would ensure the successful provision of graduates for a global tourism industry in the 1990 s and into the third millennium. The global trends taking place in the tourism industry require parallel changes in traditional tourism education toward a global tourism curriculum.

According to Altbah $(1,1999)$ : "this is the area of academic globalization" but what does this mean in tourism education?

First, it can describe the situation where tourism higher education has established itself as a worldwide phenomenon. There is huge evidence to support this. Recent surveys show 4.500 first year enrolments on about 75 degree and postgraduate courses in the UK alone. In the US there are over 500 post-secondary schools (from trade schools to major universities) teaching some aspect of tourism and the student numbers run into the many thousands. Expansion has been rapid in Australia too. This rapid expansion in course provision is reflected in many parts of the rest world.

Second, we may consider a global tourism curriculum as one that is designed to meet the needs of the global industry.

Third, global tourism curriculum designed to be marketed worldwide.

Globalization can enhance tourism education in many ways. Perhaps the most obvious benefit is that curriculum 


\section{International Journal of Science and Research (IJSR)}

ISSN (Online): 2319-7064

Index Copernicus Value (2013): 6.14 | Impact Factor (2015): 6.391

developments can assist in meeting the globalization challenges facing the industry. Smith $(6,1996)$ and Smith and Cooper $(7,1999)$ stress the importance of Global Distribution Systems, and globally standardized technical and professional skills focused around the delivery of quality service worldwide. Go (3, 1998:12-13) articulates the ten "I"s of globalization which include interdependence, innovation, information technology and interaction and explains in detail how a global curriculum can help achieve these.

\begin{abstract}
Alongside globalization is the notion of the internationalization of higher education which can exhibit a positive aspect of the globalization process. Whereas globalization implies standardization, internationalization suggests awareness and co-operation among higher education institutions on a worldwide scale. Internationalization of higher education as Hamilton (4, 1998)"the complex of processes that gives universities an internationals dimension." Thus, internationalization can be seen as relevant to all faces of university life, including scholarship, teaching, research and institutional management. It affects students, staff and curriculum development. Tourism education has benefited from email and internet developments.
\end{abstract}

Finally, a standardized global tourism curriculum can earn the study of tourism some credibility and academic rigour among other developed fields and disciplines. In terms of courses themselves, a globalize product would assist in the recognition of this type of degree, and could assist in international student and labor mobility by enabling credit accumulation and transfer and student exchanges across national boundaries. Standardization can assist in the management of quality, and a global curriculum can bring cost reductions and economies of scale particularly in the provision of learning resources.

\section{Faculty of Tourism and Hospitality - Ohrid}

The Faculty of Tourism and Hospitality - Ohrid, has existed for almost 45 years. Within this institution there are 6 active departments: Tourism, Hospitality Management, Gastronomy, Freight Forwarding, Management in Serve Sector and Insurance. The Department of tourism covers the options for hotel management, international tourism and travel agency management. The studies are interdisciplinary carried out by 18 professors, 5 associate professors and 12 teaching assistants. The teaching process includes visiting professors from the faculties, which share agreement for cooperation. Within the Faculty there is an Institute for research of the tourism as a separate unit that involves scientific and research activity. The Faculty has postgraduate courses, as well as preparation of doctorial dissertations $(\mathrm{PhD})$.

Faculty of Tourism and Hospitality aims to be an educational institution of expertise and excellence with an international orientation. The Faculty seeks to provide a stimulating workplace for its students and employees, to integrate knowledge and skills and to apply this combination to the world community in a well-considered
manner.The mission statement constitutes the basis of the institute's policy objectives:

1) To gear education to the clients (both students and the professional field);

2) To develop the position of the Faculty and its study program;

3) To attune the organization to the future form of education.

Tourism and hospitality are economic factors of increasing. Modern workforces require well-motivated individuals with the skills and adaptability to meet the demands of an ever more competitive world market for quality products. The fields of tourism and hospitality in particular, demand problem-solvers who have insight into the complex backgrounds, which are flexible and employable and have received a broad education. The reasons for this are as follows.

First, the existence of many small-scale companies is characteristic of the industry, which implies that several tasks and functions need to be combined. Furthermore, in this relatively young and topical field, new developments follow each other quickly. Insight into the nature of trends and problems and 'learning how to learn' are becoming more urgent than obtaining factual knowledge that is rapidly growing obsolete. Finally, the process of internationalization, which did not overlook the sectors mentioned, increases the importance of having insight into trends and developments, the ability to adapt quickly to new situations, and also ability to communicate internationally as well as interculturally.

In brief, Faculty of Tourism and Hospitality aims to develop managers who can operate effectively in the environment described above, which makes them attractive to prospective employees at home and abroad.

\section{Accounting - Fild of Study in Tourism Curricula}

How an organization is financed has a tremendous influence on its activities at both strategic and operation level. Finance is always a scarce resource and so usually constrains organizational planning and objectives and often dictates them. There are very few business decisions at any level, which do not have financial implications. Accounting is the medium through which financial information is reported and is therefore often claimed to be the language of business. Business managers, in whatever discipline, should have a sufficient command of this "language" maximize their effectiveness. Accounting information is employed particularly for business control and business decisionmaking.

Accounting is not, or should not be an isolated discipline but forms an integral part of all management disciplines and decision making therein. Likewise accounting should not be studied in isolation but should always be considered within the wider framework of studies on accounting to understand how the various business disciplines are inexorably linked. 


\section{International Journal of Science and Research (IJSR) \\ ISSN (Online): 2319-7064}

Index Copernicus Value (2013): 6.14 | Impact Factor (2015): 6.391

The aim of accounting as a field of study in tourism curricula is to provide an understanding of the financial framework within which a business organization operates and how financial considerations impinge upon the organisation at both strategic and operation levels. The module will therefore provide an introduction to accounting principles and techniques from a user perspective in contrast to the accountant's perspective. The focus will be on the understanding, the interpretation and the limitations of financial reports and accounting information for both external and internal users.

\subsection{The place of accounting within the faculty of tourism and hospitality - ohrid}

The subject accounting within the curriculum of the courses of Tourism and Hospitality is studied in the 2nd year. The subject is with the following number of classes:

\section{WORKLOAD: \\ Contact Time Lecturers.....2 per week performed \\ Practice. 1 per week performed}

The Accounting module learning objective is:

- To understand the fundamental purpose of financial accounting

- To formally record transactions and report on financial performance and position adhering to the fundamental concepts of accounting

- To be able to plan, prepare and use financial information to assist in effective business management and decision making

- To be able to assess and analyze business profitability, liquidity, productivity and vulnerability in a variety of ways.

- To be able to use spreadsheet models within business situations with a view to solving problems and making the most of opportunities, using sensitivity analysis.

After studying this module students should be able to:

- Explain the component parts of major accounting reports (specifically: the balance sheet, profit and lose account, cash flow statement- both historic and budgeted),

- Evaluate the financial performance of organizations from these accounting reports,

- Identify the value and limitation of accounting reports, analyze and evaluate financial information related to a product of service (explaining relationships between: volume, variable and fixed costs, contribution, profit, and selling price).

The core textbook (written specifically for this module) isAccounting: text and workbook, $5^{\text {nd }}$ edition 2012 - (Institute for Tourism research, by D. Kosarkoska)

The second edition of this book is aimed at those students who are following or intending to follow programmes of study in any part of the tourism and hospitality. From the student's point of view, this book can be used on most foundation-level accounting modules, whether they cover financial or management accounting. For the teaching institution's perspective, the book is structured to cover financial and management accounting in one single module or semester, or to cover the whole foundation accounting syllabus over a double module in one academic session.

The style and content of the text emphasizes the fundamentals of accounting, both financial accounting and management accounting. The teaching of double-entry bookkeeping in the financial accounting part of the book is carried out using the positive/negative notation, in order to make the system easier to learn, but also to lend it more easily to computer spreadsheet modelling. However, the method adopted is in no way a departure from Luka Pachioli's original and enduring system, and is simply an alternative way of presenting the same logic. This method tends to avoid the problems that many students have with the traditional double-entry system in the early stages, with its old-fashioned terminology.

During the early stages of a course, it is important that lectures should adopt the method used in the book that minimizes confusion between their method of explanation and the book's method. Lectures should explain clearly to their students that alternative methods are possible within the double-entry system, but the principles involved are essentially the same. In this way it is possible for students to read other books adopting the traditional methodology, recognising the approach taken as simply another way of presenting the identical system.

Although accounting is a largely theoretical subject, which applies broadly to a range of business sectors, this text allows the student to understand concepts, principles and techniques applied in a Tourism Hospitality context through the use of appropriated selected examples. Each chapter follows through the theory in a specific Tourism Hospitality situation, so the student can see the relevance of what they are learning, in relation to their chosen specialises.

The structure of the curriculum has the following pattern:

In the first part theoretical and methodological basics of accounting are studied :

- the role of accounting,

- the content of the accounting information system,

- the basics of the system of double-entry accounting system, through studying the most important categories and terms in the system of double-entry accounting system, account, account frame and chart of accounts, basic accounting equation and Financial statements as the synthetic "final product" of the accounting business process. These generally include an income statement, a balance sheet, and a cash flow statement.

In the second part the application of the double-entry accounting system is studied of the following:

- the fixed assets,

- the current assets,

- the obligations and

- the capital and the revenues, expenditure and the financial result.

- The third part represents only an introduction in the managing accounting, which deals with studying the Report of the sources and the use of the funds of the enterprises, analysis of the financial reports and breakevent point analysis. 


\section{International Journal of Science and Research (IJSR) \\ ISSN (Online): 2319-7064}

Index Copernicus Value (2013): 6.14 | Impact Factor (2015): 6.391

Within each part there's an emphasis on the most important issues a student should know. For example, in the part in the application of the system of double-entry accounting system of the fixed asset:

Objectives are:

- Define a fixed asset,

- Recognize that that fixed-asset values depend on a number of factors, and that the business is going a concern,

- Relate the accruals concept of accountancy to the allocation of the periodical depreciation of fixed assets against the revenues help to generate,

- Describe, justify and calculate the main methods of depreciating the cost of fixed assets,

- Record, process and report depreciation in the accounts and consider its effects on profit and financial position Understand the importance of consistency in the treatment of fixed-assets depreciation,

- Determinate and calculate the effects on profitability of purchasing and disposing of fixed assets,

- Define, identify and describe the main sources of intangible fixed-asset values, with reference to the fundamental accounting concepts of accruals, prudence and money measurement.

\subsection{Teaching and Learning Methods}

The Accounting module uses a variety of teaching and learning methods including: discussion and practical work... reading and private study ... peer group work... problem solving... lecture...drop in center...computer assisted learning packages.

Quite successful method in-group work is the case study. Samples of practical work, real situations, are given to the students and they solve them.

Users of this case study will appreciate the following issues:

- The recording of transactions in the books of account of a business,

- The recording of adjusting transactions in the books of account of a business,

- The preparation of an income statement from raw accounting data,

- The preparation of a balance sheet from raw accounting data,

- The closing off and opening of books of account of a business in consecutive years,

- The preparation of a cash flow statement,

- The preparation ratios and their interpretation.

We have been making S.W.O.T. analyses of subject accounting as a part of the curriculum of Faculty of Tourism and Hospitality - Ohrid. The main results are the following:

Strengths: High degree of compatibility in curriculum with same modules in Western University. The United States Agency for International Development (USAID), the World Bank, EU-TACIS and other organizations have established programs to assist economies in transition to make the necessary changes to their accounting systems. Some accounting reform programs $(2,1996)$ started shortly after the fall of the Berlin Wall in1989. After the Soviet Union collapsed, additional accounting reform programs were undertaken in various Southeastern European countries. Macedonia was one such republic that received USAID assistance. Also, as a result of involvement of our course in the Thempus IMG project ( 2006 ), we had an opportunity to realize the scientific stays (courses) at the respected EU Universities and as a result of that we have realized (done, performed) great number of activities such as:

- Attending lectures in Accounting, Management Accounting, Financial management, Feasibility study,

- Studying the curricula and study programs of the Accounting related courses and modules,

- Researching books, materials, journals, textbooks,

- Attending workshops specially organized for the Managers, practical researches and other employees,

- Taking active participation in many discussions in the classes of undergraduate and postgraduate students.

Thanks to this we achieved special goals like:

- The development of new courses, teaching programmes and syllabi,

- The development of new teaching materials and textbooks,

- The upgrading of technical facilities,

- University-industry cooperation.

The especially great thing about our course (subject) is a high harmonization of the teaching material with the International Accounting Standards. In the frames of every chapter there's a good explanation according to the International Accounting Standards. One of the factors that attract foreign investment is financial transparency. Investors have to know what they are investing in, and that requires financial statements that are based on some body of recognized accounting principles. There are various ways that a country can gain the confidence of foreign investors. It can adopt International Accounting Standards (IAS), since such standards are accepted in dozen of counties. It can adopt the system used in the United States, which highly regarded throughout the world by is not used in nearly as many countries as is International Accounting Standards. Or it can adopt some other system that has a high recognition factor.

Weakness: The work is done with a large number of students

The lack of technical help (instruments) for performing the lecture with the help of Computer Based Learning Packages

Development of new courses like management accounting, cost accounting

Opportunities: Updating the study programs of Accounting with too others subjects as Management accounting and Cost accounting in accordance with temporary study programs of accounting in other Faculties.

Threatens: How to develop the opinion that: the knowledge gained from an accounting education should be viewed as the student primary preparation for future successful Tourism and Hospitality Manager. 


\section{International Journal of Science and Research (IJSR) \\ ISSN (Online): 2319-7064}

Index Copernicus Value (2013): 6.14 | Impact Factor (2015): 6.391

\section{Conclusions}

The rapid spread and acceptance of globalization and the enormous developments in information technology, has led to dramatic changes in the business environment. These changes have brought new challenges not only to business but also to business (including tourism) education. Business schools that prepare future managers in different disciplines are responsible for closing the gap between the skills acquired by its graduates and the required skills by the global markets.

This paper identifies the challenges facing accounting education in providing students with the knowledge and skills that raise their competency level to meet that required by the market. These challenges warrant that the competency level of accountants should be improved. Current accounting education and the skill levels of accountants are not in line with what is required in the dynamic environments of global business. A strategic plan for closing the gap between the acquired and required skills is going to help prepare students for facing and dealing with the challenges of the new global business environment.

We can carry out the main conclusion of this study: Accounting education should develop a process of inquiry and a desire for learning in students. On our Faculty we have to develop wider choose list of accounting field subjects. We have been working on these tasks last years. This will enable accounting education to provide students with the communication, interpersonal and intellectual skills that prepare them for a better understanding of the broad picture of business in today's global environment. Based on the skills, a strategic view for meeting the market requirements should be the focus of the accounting education. The strategies must be designed to be effective applied on the principle of client-oriented education.

\section{References}

[1] AL-BALUSHI, MASOOMA and ATEF, TAMER (2013). A study of online social networks impact on potential travelers' tourism and hospitality choices. European Journal of Tourism Hospitality and Recreation ( EJTHR ), 4(1), 69-88.

[2] Altbach, P. (1999). The Perils of Internationalizing Higher Education: An Asian Perspective .Available: http://www.bc.edu/bc_org/avp/soe/cihe/direct1/News15 /text2.html

[3] Flood, B. ( 2014 ) The case for change in accounting education. The Routledge Companion to Accounting Education, Routledge Taylor \& Francis Group, 81 101.

[4] Borda, M., Mcleay, S. (1996) Accounting and Economic Transformation in Hungary, in Garrod, N., and Mcleay, S., editors, Accounting in Transition: The implications of Political and Economic Reform in Central Europe, London and New York, Routledge 116140.

[5] Go, F. (1998). Globalization and Emerging Tourism Education Issues. Paper delivered at Conference on Tourism Education Exchange, University of Westminster.
[6] Hamilton, S. (1998). Setting the foundation for the Internationalization of Australian Higher Education. Available: www.horizon.unc.edu/projects/issues/papers/ http://

[7] Kosarkoska, D. (2012). Accounting: text and workbook, $2^{\text {nd }}$ edition Institute for Tourism research - Ohrid.

[8] Kosarkoska, D. (2012). The Main Process In the Financial Reporting at the Beginning of $21^{\text {st }}$ Century. Procedia - Social and Behavioral Sciences 44:241-249. December 2012.

[9] Smith, G. (1996). International tourism and hospitality careers through education and training: A leadership challenge. Panel presentation for, East Meets West: A new Trend in World hospitality Management and Culinary Teaching, CHRIE Annual Conference, Washington DC, August 8

[10] Smith, G. and C. Cooper, (1999). The challenge of globalization from theory to practice: competitive approaches to tourism and hospitality curriculum design. Conference proceedings of the first PanAmerican Conference: Latin American Tourism in the Next Millennium Education, Investment and Sustainability: $43-57$

[11] http://sthm.temple.edu/center-studentservices/curriculum/semester-plans/

[12] http://www.edb.gov.hk/en/curriculumdevelopment/list-page.html\#

[13] http://sb.lau.edu.lb/programs/undergraduate/bshospitality-tourism/

[14] http://www.bbi-edu.eu/pdf/brochure-bbi.pdf

[15] The Government of the Hong Kong Special Administrative Region (2013).Tourism and Hospitality studies, Introduction to tourism. 